Article

\title{
Challenges and Opportunities of Aligning Forest Function Mapping and the Ecosystem Service Concept in Germany
}

\author{
André Tiemann * ${ }^{(D)}$ and Irene Ring ${ }^{(D)}$ \\ Chair of Ecosystem Services, International Institute Zittau, Technische Universität Dresden, \\ Markt 23, 02763 Zittau, Germany; irene.ring@tu-dresden.de \\ * Correspondence: andre.tiemann@tu-dresden.de; Tel.: +49-3583-612-4130
}

Received: 29 September 2018; Accepted: 4 November 2018; Published: 6 November 2018

\begin{abstract}
In the context of considering natural capital in decision-making, the ecosystem services concept is steadily increasing in importance. This also holds for the forest sector in Germany. This development calls for a harmonisation of approaches and terms used in the forest sector, as well as being made compatible with the ecosystem services concept and relevant classifications. In Germany, and a number of Central European countries, a common way to assess the multifunctional benefits of forests is the forest function mapping method. Due to the federal multi-level governance system in Germany, each state has its own classification of forest functions and mapping. A first objective of this paper is to align the various forest function categories across German states as a basis to relate them to the ecosystem services concept. Second, this bottom-up approach is combined with a top-down approach, building on the Common International Classification of Ecosystem Services (CICES). The aim is to develop a harmonised, methodological framework, suitable for accounting forest-related ecosystem services, as a step towards future ecosystem services monitoring and reporting commitments in the forest sector. Finally, the challenges and opportunities of the ecosystem services concept for forest management are discussed and ways forward are elaborated.
\end{abstract}

Keywords: ecosystem services; forest function mapping; CICES; Germany; accounting

\section{Introduction}

Forests cover almost four billion ha of land globally, amounting to about $30 \%$ of total land area [1]. Forests and their biological diversity hold special significance for the provision of ecosystem services (ESS), thus contributing to human well-being in an extraordinarily vast and far-reaching way [1]. This paper aims to harmonise the approaches and terms used in the forest sector with the ESS concept, therefore ESS are defined here according to the definition provided by Haines-Young and Potschin (2018) in their Guidance on the Common International Classification of Ecosystem Services (CICES) V5.1 [2] as "the contributions that ecosystems make to human well-being, and distinct from the goods and benefits that people subsequently derive from them." Besides providing resources like timber or fuel wood, forests also regulate water quantity and quality as well as the climate, or they protect soils against erosion and drought [3]. Furthermore, forests supply various cultural ESS such as recreation, landscape aesthetics or cultural heritage [4].

However, forests, forest biodiversity and thus the ESS that they provide are endangered. Since 1990, the global forest area has decreased by $3.1 \%$ annually, with a particularly high degree of natural forest loss in tropical countries and a worldwide increase of planted, commercially-used forest [1]. The climate protection function is particularly affected, and since 1990 the amount of carbon 
stored in biomass has declined by $0.15 \%$ annually. With the exception of Europe, Northern and Central America and Oceania, this trend can be observed worldwide.

As a response, major strategies at the policy level have been adopted to conserve forests and improve the state of biodiversity, ecosystems and ESS in the medium and long terms. The EU Forest Strategy aims to maintain, enhance and restore forests' multifunctionality and the resilience of forest ESS [5]. Another prominent example at the EU level is the EU 2020 Biodiversity Strategy [6]. The maintenance and restoration of ecosystems and their services are addressed in target 2 . These include the assessment of the economic value of such services, and promotion of their integration into accounting and reporting systems at the EU and national levels by 2020. The increased contribution of forests to maintain and enhance biodiversity is part of target 3 [6]. At the German national level, the German National Strategy on Biological Diversity defines specific fields of action such as forestry, climate change mitigation, the mitigation of ESS degradation, and strengthening cultural ESS [7].

The knowledge about the ability of forests to provide multiple services dates back to the early 19th century. According to Riegert and Bader (2010) [8], Zwierlein in 1806 [9] and Jonnès in 1825 [10] were two of the first forest scientists stressing the relevance of forest effects besides wood production. In 1953, Dieterich [11] refined their work towards the contribution of forests to human well-being. Dieterich developed the concept of forest functions, defining forest functions as societally relevant services and the capacity of forests to provide these services (see Köppel et al., 2016 [12]). Various forest functions have been distinguished and the forest function approach acted as a forerunner to the concept of multifunctional forest planning by integrating non-productive aspects as well as socio-cultural and environmental issues into decision-making [13]. According to Kindler (2016) [14], forest functions are traditionally classified according to the use, protection and recreation function of forests. Accordingly, these functions somewhat mirror the Millennium Ecosystem Assessment (MA) [15] and CICES classes of provisioning, regulating and cultural services. Nowadays, various interpretations of multifunctional forest management have found their way into Central European legal regulations, such as in Austria, Switzerland, the Czech Republic and Germany [16]. For example, the German Forest Act prescribes that in addition to the productive function, proper forest management has to ensure the maintenance of protection and recreation functions [17].

With the ESS concept becoming more prominent, developments to expand the traditional forest accounting systems by including ESS could be noted [18,19]. For instance, Elsasser et al. (2016) [20] provide insights into Austrian, German and Swiss efforts towards valuing forest ESS, with the frequency of studies over the last 20 years following an increasing trend. However, regarding an economic perspective, the concept of forest functions suffers from certain weaknesses. According to Hanewinkel (2011) [21] multifunctionality in forest management describes the provision of several forest functions at the same time and in the same area. The author states that forest functions are rarely quantified and spatial or temporal objectives are often not available; therefore, the operationalisation of individual forest functions is only possible in very few cases (e.g., use function).

Therefore, extending the multifunctional forest management system through the ESS approach could be one option to assess forest services [21]. Meyer and Schulz (2017) [22] discuss the added value of ESS compared to existing forest planning approaches and highlight the opportunity of the ESS approach to prioritise forest benefits and analyse interactions and trade-offs between different benefits. They also highlight the flexibility of the ESS approach as a potential advantage in shaping forest governance.

A promising base for an implementation of the ESS perspective in the forest sector is the forest function mapping (FFM) approach as the tool for an integrative consideration of various forest functions in planning and operation [23,24]. Since the use function of forests (timber provision) has always been accounted for in forest agencies [11], the main objective of FFM is to assess and map all forest areas with a particular importance for protection and recreation [19]. This is one reason why FFM is widely used as a common planning tool in Germany and many Central European countries [16]. 
Furthermore, there are similarities between FFM and the ESS concept, such as overlapping categories or the consideration of similar benefits $[14,22,25,26]$.

The Common International Classification of Ecosystem Services (CICES) was developed to provide a classification of ecosystem goods and services that is consistent with already accepted typologies; for example, building on the MA [15] and the TEEB initiative on the Economics of Ecosystem and Biodiversity [27]. At the same time, it was developed to be compatible with accounting methods, considered in the System of Environmental-Economic Accounting (SEEA) [28]. Furthermore, it was designed to link data on ecosystem structure, dynamics of ecosystems and information on economic performance [29]. CICES is structured hierarchically and comprises Sections, which correspond to the MA categories of provisioning, regulating and cultural services. These Sections are further divided into Divisions, Groups, and Classes. Within Classes, additional Types and Sub-types can be recognised which allow for an application to particular geographical regions [2].

A comprehensive application of the CICES Framework for Finnish boreal forests can be found in Saastamoinen et al. (2014) [30]. The authors identified and classified nearly 50 ESS classes (e.g., forest biomass, mass stabilisation and control of erosion rates, aesthetic) with more than 100 Class types (e.g., solid wood fuel, water erosion mediation by forests, national parks). They consider CICES as a powerful tool to identify, investigate and classify ESS. Hansen and Malmaeus (2016) [31] provide another valuable example for the application of CICES in forestry. They identified 22 forest ESS, developed indicators and provided economic values where available. They also pointed to the partial lack of adequate indicators, especially for regulating services.

For Germany, Köppel et al. (2016) [12] adapted forest functions based on the federal FFM guideline [24] to CICES ESS categories, and thus provided a first valuable basis for implementing the ESS concept in forest planning and operation. They underline opportunities such as the potential for improved interdisciplinary collaboration or improved communication for the relevance of ESS for society. However, they are also aware of risks, such as the need for additional human and financial resources to assess ESS. In addition, Köppel et al. (2016) [12] emphasised the necessity of further research that takes into account the specificities of both the federal and various state guidelines in Germany, which has been taken as a starting point for aligning FFM and the ESS concept in the present paper.

Beyond Germany, the European State Forest Association (EUSTAFOR) represents State Forest Associations in 22 European countries and highlights the strong relevance of describing and assessing forest ESS in Europe, as well as the need for research on forest ecosystems as "a major source of highly valued goods and services" [32]. The association further highlights the importance of a common language, which can be achieved by the ESS approach. Simoncic et al. (2015) [33] identified the consideration of diverse societal values as a challenge in forest planning for many years. The authors mention the spatial classification of forest areas as a possible solution to this problem. They introduce a conceptual framework to characterise forest priority areas, building —among others-on the German FFM approach as one of their most extensive references for international comparative purposes.

FFM provides highly differentiated information, whereby its widespread and long-term use as a common planning tool in Germany and Central Europe [16] renders FFM a suitable basis for comprehensively integrating ESS into forest operation and planning.

Therefore, the primary purpose of this paper is to provide a classification of ESS, which may support European state forest agencies with a multifunctional forest management system in implementing an ESS perspective in forest planning and management. This work could also serve as a basis for future forest ecosystem accounting studies and reporting commitments in the forest sector. Since FFM is well-established in Central European forest authorities and the German FFM guidelines have already proved to provide a valuable basis for international comparative purposes [33], we use the German FFM approach as a starting point. Therefore, one core element of this research is the harmonisation of German FFM state guidelines and the federal guideline with each other. Another core element of this research is the presentation of a customised CICES Framework-using 
the latest, updated version of the CICES V5.1 Framework [34] - that represents the FFM content in a comprehensive and precise manner.

The paper is structured as follows: Section 2 outlines our methodological approach to harmonise German FFM and the CICES Framework while Section 3 presents the results in the form of the customised CICES Framework. Finally, the opportunities and challenges of aligning the concepts of ESS and FFM are discussed in Section 4 before concluding in Section 5.

\section{Materials and Methods}

\subsection{Combining a Bottom-Up and a Top-Down Approach}

In this section, a methodological approach is introduced, which aligns terminologies used in the FFM guidelines with the ESS concept. Special emphasis is placed on refining the already existing concept of FFM. Due to its international applicability (see Simoncic et al., 2015 [33]) the German FFM was chosen as an example. With few exceptions, provisioning services were not taken into account as the use functions of forests (e.g., timber) have always been accounted for in forest agencies [11] and the main objective of FFM is to assess and map all forest areas with a particular importance for protection and recreation [19].

The methodological approach to align FFM and the ESS concept comprises combining a bottom-up with a top-down approach to reconcile concepts of two different governmental levels. The FFM approach is a national concept, designed at a decentralised level (bottom-up). Due to the federal, multi-level structure of the government system in Germany (see below), the majority of German state forest agencies have formulated their own FFM guidelines, to best represent their individual needs. In contrast, CICES - as an internationally applicable concept-is designed at a centralised level (top-down). In this research, the interface between these two levels is called the intermediate level, where the common denominator (FFM-CICES Synthesis) serves as a translator between the common international classification at a centralised level and the more specific, national concept at decentralised governmental levels (see Figure 1).

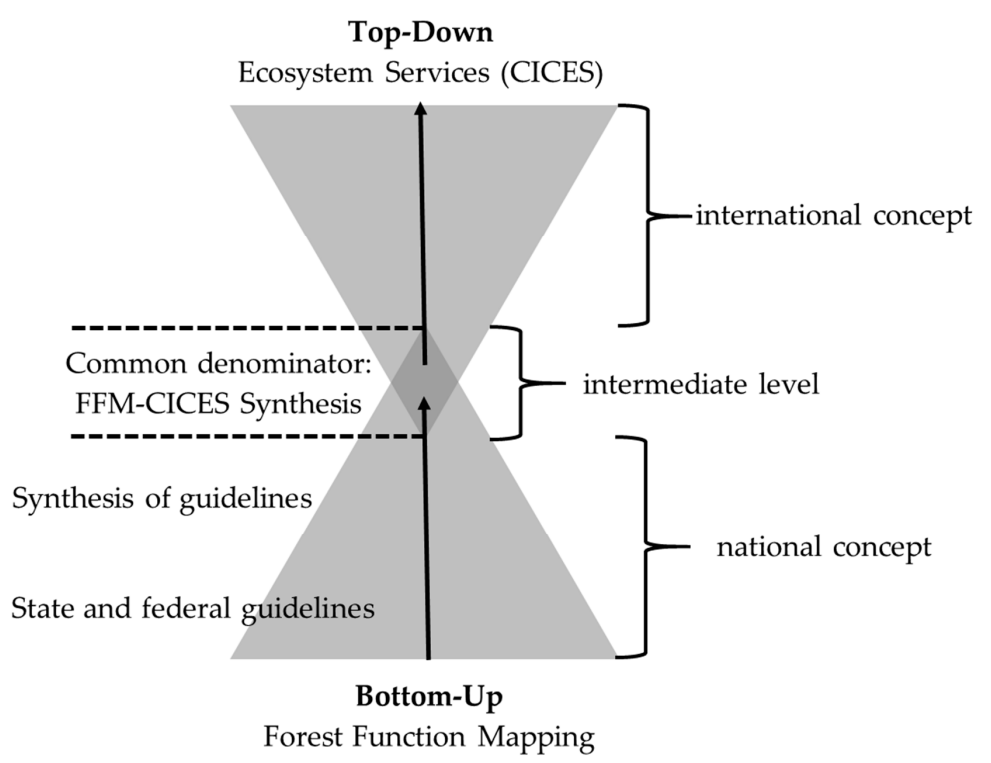

Figure 1. Combining a bottom-up approach with a top-down approach to harmonise forest function mapping (FFM) in federal systems and the Common International Classification of Ecosystem Services (CICES). Source: own representation.

Due to the federal, multi-level structure of the government system, Germany comprises 16 states (Länder), 13 so-called area states (Flächenländer) and the three city states (Stadtstaaten) of Berlin, Hamburg and Bremen. As the three city states do not apply FFM, we will focus on the area states 
that each have an independent state forest agency [35]. Therefore, a large number of individual state guidelines exist for the classification and practical implementation of FFM. At the national level, there is a federal guideline aiming to provide a central, harmonised methodology and framework guideline for all states [24]. In the following the federal guideline and six FFM state guidelines are reviewed to develop a harmonised terminology in view of the ESS concept. As the four states of North Rhine-Westphalia, Baden-Württemberg, Hesse and Bavaria have already largely adopted the federal guideline [24], the accessible individual state guidelines for the states of Mecklenburg Western Pomerania [36], Lower Saxony [37], Brandenburg [38], Saxony [39], Thuringia [40] and Rhineland Palatinate [41] are reviewed. Instead of using an individual FFM guideline, the State Forest Agency of Schleswig-Holstein rather applies an extensive GIS system with over 100 layers (e.g., nature forest, NATURA 2000 Sites, forests of relevance for gene resources, etc.). In the state of Saarland, instead of an individual FFM guideline, all legally designated protected areas are defined as a part of forest planning. In addition, a forest biotope mapping is carried out for the entire forest area.

Despite fundamental commonalities between the state and federal guidelines in characterising and mapping forest functions, there are also significant differences in their practical application. These differences - particularly related to the terminology used, the way of considering forest functions at the management level and the level of topicality-affect the comparability and clarity at the national level [25].

\subsection{Harmonising FFM Guidelines}

Figure 1 visualises how information from the FFM methodology was brought into an ESS perspective by using a common denominator. The first step was online research for accessing available FFM guidelines. Building on this, the description of each FFM category (state and federal) was reviewed in a content analysis process, identifying terms used to define and describe related functional aspects, that were recorded in a cross table (Table 1). This structure allowed the synthesis of state guidelines among themselves as well as the federal guideline. The FFM Synthesis contains the overall information of the state guidelines as well as the federal guideline to become a basis for further processing. In this process, duplicates due to coincident functional aspects were eliminated, functional aspects with a similar meaning but a different terminology were synthesised into a generalised term that preserves the overall information, and content that does not exist in certain guidelines was considered in the FFM Synthesis. Accordingly, the procedure adopted follows an inductive approach of developing categories from an existing database [42]. Table 1 is an exemplary representation of this process.

Table 1. Synthesis of state and federal forest function mapping (FFM) guidelines. Source: own representation. $\checkmark$ Same terms used; $\varnothing$ Terms not present.

\begin{tabular}{|c|c|c|c|c|c|c|}
\hline \multirow{2}{*}{ FFM Category } & \multicolumn{5}{|c|}{ Terms Used to Define and Describe Functional Aspects in FFM Guidelines } & \multirow{2}{*}{ FFM Synthesis } \\
\hline & Federal & Saxony & Brandenburg & Thuringia & State $_{n}$ & \\
\hline \multirow{2}{*}{$\begin{array}{l}\text { Water Protecting } \\
\text { Forest }\end{array}$} & $\begin{array}{c}\text { Keeping } \\
\text { surface water } \\
\text { pure }\end{array}$ & $\checkmark$ & $\checkmark$ & $\checkmark$ & $\cdots$ & $\begin{array}{l}\text { Keeping surface } \\
\text { water pure }\end{array}$ \\
\hline & $\begin{array}{c}\text { Keeping } \\
\text { groundwater } \\
\text { pure }\end{array}$ & $\checkmark$ & $\checkmark$ & $\checkmark$ & $\ldots$ & $\begin{array}{l}\text { Keeping } \\
\text { groundwater pure }\end{array}$ \\
\hline$\ldots$ & $\ldots$ & $\ldots$ & $\ldots$ & $\ldots$ & $\ldots$ & $\ldots$ \\
\hline \multirow{2}{*}{$\begin{array}{l}\text { Street Protecting } \\
\text { Forest }\end{array}$} & $\varnothing$ & $\begin{array}{l}\text { Protecting } \\
\text { streets against } \\
\text { landslides }\end{array}$ & $\begin{array}{l}\text { Protecting } \\
\text { streets against } \\
\text { rockfall }\end{array}$ & $\begin{array}{l}\text { Protecting } \\
\text { streets against } \\
\text { rockfall }\end{array}$ & $\ldots$ & $\begin{array}{c}\text { Protecting streets } \\
\text { against solid mass } \\
\text { movement }\end{array}$ \\
\hline & $\varnothing$ & $\begin{array}{l}\text { Protecting } \\
\text { streets against } \\
\text { windblown } \\
\text { snow }\end{array}$ & $\varnothing$ & $\begin{array}{l}\text { Protecting } \\
\text { streets against } \\
\text { windblown } \\
\text { snow }\end{array}$ & $\cdots$ & $\begin{array}{l}\text { Protecting streets } \\
\text { against } \\
\text { windblown snow }\end{array}$ \\
\hline$\ldots$ & $\ldots$ & $\ldots$ & $\ldots$ & $\ldots$ & $\ldots$ & $\ldots$ \\
\hline
\end{tabular}

The FFM category Water Protecting Forest serves as an example for eliminating duplicates in the cross table. In the state guidelines, as well as in the federal guideline, the functional aspects Keeping 
surface water pure and Keeping groundwater pure are addressed. Therefore, each of these terms was arranged in a separate table row without any changes. In certain state guidelines, functional aspects are varying regarding details in the description. For example, relating to the FFM category Street Protecting Forest, the guideline of Brandenburg is emphasising the protection against landslides [38], while in Saxony and Thuringia rockfall is also addressed [39,40]. Therefore, this information is synthesised into the generalised term Protecting streets against solid mass movement to preserve the overall information. Regarding the functional aspect Protecting streets against windblown snow, this term is missing in certain guidelines and the cross tables' structure contributes to the completion of this functional aspect.

\subsection{Finding the Common Denominator}

Formulating a common denominator as the synthesis between the FFM approach and the ESS concept occurred at the intermediate level (see Figure 1). Table 2 visualises the synthesis process.

Table 2. Deriving a synthesis between FFM Synthesis and CICES at Class level. Source: own representation. Grey-shaded cells contain a synthesis between CICES Class and German FFM terminology, due to a complementary and more differentiated level of information in either FFM or CICES.

\begin{tabular}{|c|c|c|c|c|}
\hline FFM Category & FFM Synthesis & $\begin{array}{c}\text { FFM-CICES Synthesis at } \\
\text { the Class level }\end{array}$ & CICES Class & CICES Section \\
\hline \multirow{4}{*}{$\begin{array}{c}\text { Water Protecting } \\
\text { Forest }\end{array}$} & & Surface water for drinking & Surface water for drinking & \\
\hline & $\begin{array}{l}\text { Securing surface } \\
\text { water resources }\end{array}$ & $\begin{array}{l}\text { Surface water used as a } \\
\text { material (non-drinking } \\
\text { purpose) }\end{array}$ & $\begin{array}{l}\text { Surface water used as a } \\
\text { material (non-drinking } \\
\text { purpose) }\end{array}$ & Provisioning (abiotic) \\
\hline & $\begin{array}{c}\text { Keeping } \\
\text { groundwater pure }\end{array}$ & $\begin{array}{l}\text { Regulation of the chemical } \\
\text { condition of freshwaters by } \\
\text { living processes } \\
\text { (groundwater) }\end{array}$ & \multirow{2}{*}{$\begin{array}{l}\text { Regulation of the chemical } \\
\text { condition of freshwaters by } \\
\text { living processes }\end{array}$} & \multirow{2}{*}{$\begin{array}{c}\text { Regulation \& } \\
\text { Maintenance (biotic) }\end{array}$} \\
\hline & $\begin{array}{l}\text { Keeping surface } \\
\text { water pure }\end{array}$ & $\begin{array}{l}\text { Regulation of the chemical } \\
\text { condition of freshwaters by } \\
\text { living processes (surface } \\
\text { water) }\end{array}$ & & \\
\hline
\end{tabular}

A first step was to compare the content of the FFM Synthesis and the CICES Classes to identify similar content, such as Securing surface water resources and Surface water for drinking, respectively Surface water used as a material (non-drinking purpose). Subsequently, similar content was assigned to each other in a cross table. In a second step, matching content was analysed for deviations at a more detailed level of information. In the column FFM-CICES Synthesis at the Class level, the first two rows in Table 2 show a distinction between surface water for drinking and non-drinking purposes at the CICES Class level, which cannot be found at the FFM Synthesis level. Therefore, the more detailed content from the CICES Class was considered in the FFM-CICES Synthesis. The last two rows in the column FFM-CICES Synthesis at the Class level of Table 2 show a distinction between the origin of water (groundwater, surface water) in the FFM Synthesis, which cannot be found at the CICES Class level. In this case, the more detailed information considered in the FFM-CICES Synthesis stems from the FFM Synthesis.

\section{Results}

\subsection{A Customised CICES Framework}

A major outcome of this work is a CICES Framework customised for practical application in state forest agencies to identify ESS at the relevant spatial level, based on existing data from FFM. In the framework presented in the following sub-sections and Tables 3-5, all functional aspects of the FFM approach are reproduced in a comprehensive and precise manner and translated into ESS. Tables 3-5 directly build on the CICES Framework, including all ESS from CICES relevant for the forest sector. Information at the Section, Division and Group levels as well as Code numbers are identical with CICES wording. At the Class level, any plain text in cells on white background represents original 
CICES wording. Grey-shaded cells at the Class level contain a synthesis between CICES and German FFM terminologies, due to complementary and more differentiated information relevant for forestry in Germany. If existing CICES Classes have been sub-divided due to FFM detail necessary, the CICES Code numbers have been expanded by letters $(a, b, c)$. Furthermore, customised descriptions and examples were added to ease the identification of forest-related ESS by end users, while staying as close as possible to the original CICES Framework [34] as well as the reviewed FFM guidelines. Underlined text is inspired by Turkelboom et al. (2013) [43] and Saastamoinen et al. (2014) [30].

\subsection{Provisioning Services}

Table 3 shows the customised CICES Framework for provisioning services, identified in the FFM guidelines. Due to the importance of forests for providing water resources, water provisioning services are considered as the only abiotic CICES Section in this publication. The biotic services contain the provision of (woody) biomass for different purposes and the provision of genetic material. The abiotic services contain the provision of water.

The biomass Division is sub-divided into two CICES Groups, whereby the first includes cultivated, terrestrial plants and the second covers wild plants. The provision of cultivated plants at the CICES Class level describes their utilisation for direct use or processing (excluding genetic materials), while the provision of wild plants is related to their use as a source of energy. This distinction is based on the assumption that timber is provided predominantly by industrial forests, rather than natural forests. The provision of wood for energetic purposes has been assigned to the CICES Class of Wild plants (terrestrial and aquatic, including fungi, algae) used as a source of energy since cultivated plants in terms of an energetic purpose are described as plantations by CICES [34]. However, according to Germany's Federal Forest Act [17] § 2, plantations with a life cycle of less than 20 years are not forests within the meaning of the law.

The CICES Division Genetic material from all biota (including seed, spore or gamete production) contains only one CICES Group, namely Genetic material from plants, algae or fungi, and is sub-divided in two CICES Classes. Here, a distinction into forest reproductive material that was grown from harvested seeds or spores and material derived from higher and lower plants (e.g., seedlings) was implemented.

The CICES Division of water is part of the CICES Section of abiotic provisioning services and is subdivided into two CICES Groups, which enable a distinction into water used for nutrition, materials or energy from surface water sources and from groundwater sources. These two Groups are sub-divided into two further Classes, respectively, which allow an allocation to drinking water and non-drinking water. 
Table 3. Customised CICES Framework for provisioning services (biotic and abiotic). Source: own representation. Underlined text is inspired by ${ }^{(1)}$ [43] and ${ }^{(2)}$ [30].

\begin{tabular}{|c|c|c|c|c|c|c|}
\hline Section & Division & Group & Class & Code & Customised Description & Customised Example \\
\hline \multirow{4}{*}{$\begin{array}{l}\text { Provisioning } \\
\quad \text { (biotic) }\end{array}$} & \multirow{2}{*}{ Biomass } & $\begin{array}{l}\text { Cultivated terrestrial } \\
\text { plants for nutrition, } \\
\text { materials or energy }\end{array}$ & $\begin{array}{c}\text { Fibres and other materials from } \\
\text { cultivated plants, fungi, algae and } \\
\text { bacteria for direct useo processing } \\
\text { (excluding genetic materials) }\end{array}$ & 1.1.1.2 & $\begin{array}{l}\text { Wood-based resource production potential in a } \\
\text { particularly high degree }\end{array}$ & $\begin{array}{l}\text { Provision of renewable, climate-friendly } \\
\text { resources (e.g., construction-, furniture--, paper, } \\
\text { chemical producing industry ...) }\end{array}$ \\
\hline & & $\begin{array}{l}\text { Wild plants } \\
\text { (terrestrial and } \\
\text { aquatic for nutrition, } \\
\text { materials or energy }\end{array}$ & $\begin{array}{l}\text { Wild plants (terrestrial and aquatic, } \\
\text { including fungi, algae) used as a } \\
\text { source of energy }\end{array}$ & 1.1.5.3 & $\begin{array}{l}\text { Wood-based energy resource production potential } \\
\text { in a particularly high degree }\end{array}$ & $\begin{array}{l}\text { Provision of renewable, climate-friendly energy } \\
\text { resources (e.g., fuel wood, } \\
\text { cutting residuals, process-by-products } \\
\left.{ }^{(2)}, \ldots\right)\end{array}$ \\
\hline & \multirow{2}{*}{$\begin{array}{l}\text { Genetic material from } \\
\text { all biota (including } \\
\text { seed, spore or gamete } \\
\text { production) }\end{array}$} & \multirow{2}{*}{$\begin{array}{l}\text { Genetic material from } \\
\text { plants, algae or fungi }\end{array}$} & $\begin{array}{l}\text { Seeds, spores and other plant } \\
\text { materials collected for maintaining } \\
\text { or establishing a population }\end{array}$ & 1.2.1.1 & $\begin{array}{l}\text { Extraction of tree seeds for the production of } \\
\text { forest reproductive material }\end{array}$ & $\begin{array}{l}\text { Provision of properly identified forest } \\
\text { reproductive material; maintaining and } \\
\text { improving forests genetic diversity and functional } \\
\text { performance (seeds) }\end{array}$ \\
\hline & & & $\begin{array}{l}\text { Higher and lower plants (whole } \\
\text { organisms) used to breed new } \\
\text { strains or varieties }\end{array}$ & 1.2.1.2 & $\begin{array}{l}\text { Extraction of trees for the production of forest } \\
\text { productive material }\end{array}$ & $\begin{array}{c}\text { Provision of properly identified forest } \\
\text { reproductive material; maintaining and } \\
\text { improving forests genetic diversity and functional } \\
\text { performance (plants) }\end{array}$ \\
\hline \multirow{4}{*}{$\begin{array}{l}\text { Provisioning } \\
\quad \text { (abiotic) }\end{array}$} & \multirow{4}{*}{ Water } & \multirow{2}{*}{$\begin{array}{l}\text { Surface water used } \\
\text { for nutrition, } \\
\text { materials or energy }\end{array}$} & Surface water for drinking & 4.2.1.1 & $\begin{array}{l}\text { Quantity of drinking water from } \\
\text { rivers, lakes, reservoirs, collected precipitation }{ }^{(1)} \\
\end{array}$ & Drinking water for domestic use \\
\hline & & & $\begin{array}{l}\text { Surface water used as a material } \\
\text { (non-drinking purposes) }\end{array}$ & 4.2.1.2 & $\begin{array}{l}\text { Quantity of non-drinking water from } \\
\text { rivers, lakes, reservoirs, collected precipitation }\end{array}$ & 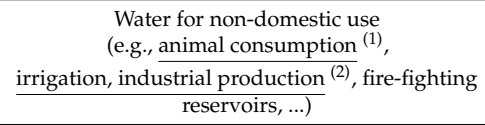 \\
\hline & & \multirow{2}{*}{$\begin{array}{l}\text { Groundwater used } \\
\text { for nutrition, } \\
\text { materials or energy }\end{array}$} & $\begin{array}{l}\text { Groundwater (and subsurface water) } \\
\text { for drinking }\end{array}$ & 4.2.2.1 & $\begin{array}{l}\text { Quantity of drinking water from } \\
\text { springs, (non-fossil) aquifers }{ }^{(1)}\end{array}$ & Drinking water for domestic use \\
\hline & & & $\begin{array}{l}\text { Groundwater (and subsurface water) } \\
\text { used as a material (non-drinking } \\
\text { purposes) }\end{array}$ & 4.2.2.2 & $\begin{array}{l}\text { Quantity of non-drinking water from } \\
\text { springs, (non-fossil) aquifers }{ }^{(1)}\end{array}$ & $\begin{array}{c}\text { Water for non-domestic use } \\
\begin{array}{c}\text { (e.g., animal consumption } \\
(1),\end{array} \\
\frac{\text { irrigation, industrial production }}{{ }^{(2)} \text {, fire-fighting }} \\
\text { reservoirs, ...) }\end{array}$ \\
\hline
\end{tabular}


Table 4. Customised CICES Framework for regulating services (biotic). Source: own representation. Grey-shaded cells contain a synthesis between CICES and German FFM terminology, due to a complementary and more differentiated level of information. Underlined text is inspired by (1) [43] and ${ }^{(2)}$ [30]

\begin{tabular}{|c|c|c|c|c|c|c|}
\hline Section & Division & Group & Class & Code & $\begin{array}{c}\text { Customised Description } \\
\end{array}$ & Customised Example \\
\hline \multirow{14}{*}{$\begin{array}{l}\text { Regulation \& } \\
\text { Maintenance } \\
\quad \text { (Biotic) }\end{array}$} & \multirow{4}{*}{$\begin{array}{l}\text { Transformation of } \\
\text { biochemical or } \\
\text { physical inputs to } \\
\text { ecosystems }\end{array}$} & \multirow{2}{*}{$\begin{array}{l}\text { Mediation of wastes or } \\
\text { toxic substances of } \\
\text { anthropogenic origin by } \\
\text { living processes }\end{array}$} & $\begin{array}{l}\text { Filtration/sequestration/storage/ } \\
\text { accumulation by micro-organisms, algae, } \\
\text { plants, and animals at local scale }\end{array}$ & 2.1.1.1-a & $\begin{array}{c}\text { Capturing/filtering (fine) dust, chemicals and smells }{ }^{(1)} \\
\text { by trees between a known emitter and an area to be } \\
\text { protected }\end{array}$ & \multirow{4}{*}{ Improved life quality for humans } \\
\hline & & & $\begin{array}{l}\text { Filtration/sequestration/storage/ } \\
\text { accumulation by micro-organisms, algae, } \\
\text { plants, and animals at regional scale }\end{array}$ & 2.1.1.1-b & $\begin{array}{c}\text { Capturing/filtering (fine) dust, chemicals and smells } \\
\text { by trees in a polluted area, where a certain emitter is } \\
\text { unknown }\end{array}$ & \\
\hline & & \multirow{2}{*}{$\begin{array}{l}\text { Mediation of nuisances of } \\
\text { anthropogenic origin }\end{array}$} & Noise attenuation & 2.1.2.2 & Buffering of noise by forests & \\
\hline & & & Visual screening & 2.1 .2 .3 & Hiding unwelcome visual impacts by forests & \\
\hline & \multirow{10}{*}{$\begin{array}{l}\text { Regulation of } \\
\text { physical, chemical, } \\
\text { biological conditions }\end{array}$} & \multirow{6}{*}{$\begin{array}{l}\text { Regulation of baseline } \\
\text { flows and extreme events }\end{array}$} & Control of water-induced erosion rates & 2.2.1.1-a & $\begin{array}{l}\text { The capacity of vegetation to prevent or reduce leaching } \\
\text { of sediments (e.g., nutrients, toxic substances, ...) into } \\
\text { surface water; Water capacity increase of soils by roots; } \\
\text { Reduction of precipitation quantity and -intensity } \\
\text { reaching the ground by forest biomass }\end{array}$ & $\begin{array}{l}\text { Reduction of damage (and associated costs) of } \\
\text { sediment input to water courses; Protection } \\
\text { against erosion damages caused by water } \\
\text { (e.g., washing out, running-off soil and humus) }\end{array}$ \\
\hline & & & Control of wind-induced erosion rates & 2.2.1.1-b & $\begin{array}{l}\text { Wind speed reduction by trees, shrubs and ground cover } \\
\text { vegetation; Soil anchoring by roots }\end{array}$ & $\begin{array}{l}\text { Protection against erosion damages caused by } \\
\text { wind (e.g., blowing off soil and humus) }\end{array}$ \\
\hline & & & $\begin{array}{l}\text { Buffering and attenuation of mass } \\
\text { movement }\end{array}$ & 2.2.1.2 & $\begin{array}{l}\text { Avalanche volume reduction by forests; Soil anchoring } \\
\text { by roots }\end{array}$ & $\begin{array}{l}\text { Protection against erosion damages caused by } \\
\text { solid mass movement such as rock-, soil-, snow } \\
\text { (e.g., settlements, roads and other facilities, ...) }\end{array}$ \\
\hline & & & $\begin{array}{c}\text { Hydrological cycle and water flow } \\
\text { regulation (Incl. flood control, and } \\
\text { coastal protection) }\end{array}$ & 2.2.1.3 & $\begin{array}{l}\text { Water balance regulation, water retention, water flow } \\
\text { control by forests }\end{array}$ & $\begin{array}{l}\text { Protection against damages caused by floods } \\
\text { (e.g., humans, facilities, nature, ... ) }\end{array}$ \\
\hline & & & Wind protection & 2.2.1.4 & $\begin{array}{l}\text { Wind speed reduction by trees, shrubs and ground cover } \\
\text { vegetation; Volume reduction of matter blown in } \\
\text { (e.g., snow, fog) }\end{array}$ & $\begin{array}{l}\text { Protection against wind/storm; matter blown in } \\
\text { by wind (e.g., snow, fog); Protection of storm } \\
\text { threatened forest stands, settlements, roads and } \\
\text { vehicle drivers }\end{array}$ \\
\hline & & & Fire protection & 2.2.1.5 & $\begin{array}{l}\text { Wild fire risk reduction by flame retardant tree- and } \\
\text { shrub species, shaded soil, special dead-and dry tree } \\
\text { management in wild fire protection areas or stripes }\end{array}$ & $\begin{array}{l}\text { Protection against fire damages (e.g., humans, } \\
\text { facilities, nature, ...) }\end{array}$ \\
\hline & & $\begin{array}{l}\text { Lifecycle maintenance, } \\
\text { habitat and gene pool } \\
\text { protection } \\
\end{array}$ & $\begin{array}{l}\text { Maintaining nursery populations and } \\
\text { habitats (Including gene pool protection) }\end{array}$ & 2.2.2.3 & $\begin{array}{l}\text { Forest that serves as habitats for (endangered) species; } \\
\text { Structurally rich forest stands, with a high variety of } \\
\text { animal- and plant species }\end{array}$ & $\begin{array}{l}\text { Providing habitats for (endangered) species } \\
\text { (e.g., Deadwood); Increased resistance of species } \\
\text { against diseases in diverse forests }\end{array}$ \\
\hline & & Regulation of soil quality & $\begin{array}{l}\text { Decomposition and fixing processes and } \\
\text { their effect on soil quality }\end{array}$ & 2.2.4.2 & $\begin{array}{l}\text { Humification and nutrient input into soils, especially by } \\
\text { forests with (a certain amount of) deciduous tree species }\end{array}$ & $\begin{array}{l}\text { Maintaining soil characteristics necessary for } \\
\text { human use }\end{array}$ \\
\hline & & \multirow[t]{2}{*}{ Water conditions } & $\begin{array}{l}\text { Regulation of the chemical condition of } \\
\text { freshwaters by living processes } \\
\text { (groundwater) }\end{array}$ & 2.2.5.1-a & $\begin{array}{l}\text { Filtration of hazardous substances } \\
\text { from water (rhizofiltration) })^{(2)} \text { seeping to lower soil } \\
\text { layers and into the groundwater (also holds for mineral } \\
\text { springs) }\end{array}$ & $\begin{array}{l}\text { Maintaining chemical condition of fresh waters } \\
\text { (groundwater) to enable human use or health }\end{array}$ \\
\hline & & & $\begin{array}{l}\text { Regulation of the chemical condition of } \\
\text { freshwaters by living processes } \\
\text { (surface water) }\end{array}$ & 2.2.5.1-b & $\begin{array}{l}\text { Filtration of hazardous substances } \\
\text { from water (rhizofiltration) } \\
\text { water } \\
\text { watreaming into surface }\end{array}$ & $\begin{array}{l}\text { Maintaining chemical condition of fresh waters } \\
\text { (surface water) to enable human use or health }\end{array}$ \\
\hline
\end{tabular}


Table 4. Cont.

\begin{tabular}{|c|c|c|c|c|c|c|}
\hline Section & Division & Group & Class & Code & Customised Description & Customised Example \\
\hline \multirow{4}{*}{$\begin{array}{l}\text { Regulation \& } \\
\text { Maintenance } \\
\quad \text { (Biotic) }\end{array}$} & \multirow{4}{*}{$\begin{array}{c}\text { Regulation of } \\
\text { physical, chemical, } \\
\text { biological conditions }\end{array}$} & \multirow{4}{*}{$\begin{array}{l}\text { Atmospheric composition } \\
\text { and conditions }\end{array}$} & $\begin{array}{l}\text { Regulation of chemical composition of } \\
\text { atmosphere and oceans }\end{array}$ & 2.2.6.1 & $\begin{array}{l}\text { Carbon sequestration and storage by trees on high } \\
\text { performance stands }\end{array}$ & $\begin{array}{l}\text { Global climate regulation to maintain living } \\
\text { conditions }\end{array}$ \\
\hline & & & $\begin{array}{l}\text { Regulation of temperature and humidity, } \\
\text { including ventilation and transpiration } \\
\text { at the micro-climate level }\end{array}$ & 2.2.6.2-a & $\begin{array}{l}\text { Forested areas, with a climatic impact on nearby, small } \\
\text { areas }\end{array}$ & $\begin{array}{c}\text { Equalisation of temperature and humidity } \\
\text { extremes or improve living conditions for species } \\
\text { or humans (e.g., parts of surface waters, single } \\
\text { buildings, ...) }\end{array}$ \\
\hline & & & $\begin{array}{l}\text { Regulation of temperature and humidity, } \\
\text { including ventilation and transpiration } \\
\text { at the local level }\end{array}$ & $2.2 .6 .2-\mathrm{b}$ & $\begin{array}{l}\text { Forested areas, with a climatic impact on nearby, larger } \\
\text { objects or local areas }\end{array}$ & $\begin{array}{l}\text { Equalisation of temperature and humidity } \\
\text { extremes or improve living conditions for species } \\
\text { or humans (e.g., parts of agricultural fields, forest } \\
\text { rejuvenation areas, facilities, clusters of several } \\
\text { buildings, ...) }\end{array}$ \\
\hline & & & $\begin{array}{c}\text { Regulation of temperature and humidity, } \\
\text { including ventilation and transpiration } \\
\text { at the regional level }\end{array}$ & 2.2.6.2-c & $\begin{array}{l}\text { Forested areas, with a climatic impact on larger areas at } \\
\text { the regional level }\end{array}$ & $\begin{array}{l}\text { Equalisation of temperature and humidity } \\
\text { extremes or improve living conditions for species } \\
\text { or humans (e.g., densely populated areas, urban } \\
\text { agglomerations, ...) }\end{array}$ \\
\hline
\end{tabular}


Table 5. Customised CICES Framework for cultural services (biotic). Source: own representation. Underlined text is inspired by ${ }^{(1)}$ [43] and ${ }^{(2)}$ [30].

\begin{tabular}{|c|c|c|c|c|c|c|}
\hline Section & Division & Group & Class & Code & Customised Description & Customised Example \\
\hline \multirow{9}{*}{ Cultural (Biotic) } & \multirow{6}{*}{$\begin{array}{l}\text { Direct, in-situ and } \\
\text { outdoor interactions } \\
\text { with living systems } \\
\text { that depend on } \\
\text { presence in the } \\
\text { environmental setting }\end{array}$} & \multirow{2}{*}{$\begin{array}{l}\text { Physical and } \\
\text { experiential } \\
\text { interactions with } \\
\text { natural environment }\end{array}$} & $\begin{array}{l}\text { Characteristics of living systems that } \\
\text { enable activities promoting health, } \\
\text { recuperation or enjoyment through } \\
\text { active or immersive interactions }\end{array}$ & 3.1.1.1 & $\begin{array}{l}\text { Forested areas, where nature experience is a secondary } \\
\text { motivation. The activity itself (e.g., walking, cycling, } \\
\text { horse riding, } \ldots \text { ) is the central concern of recreation }\end{array}$ & $\begin{array}{l}\text { Improved physical, social, mental well-being, } \\
\text { motoric development }{ }^{(1)} \text {, health aspects }\end{array}$ \\
\hline & & & $\begin{array}{l}\text { Characteristics of living systems that } \\
\text { enable activities promoting health, } \\
\text { recuperation or enjoyment through } \\
\text { passive or observational interactions }\end{array}$ & 3.1.1.2 & $\begin{array}{l}\text { Forested areas, where the recreational purpose is } \\
\text { primarily connected to a conscious perception of nature } \\
\text { (e.g., forest characteristics, smells, sounds, ...) }\end{array}$ & $\begin{array}{c}\text { Improved } \\
\frac{\text { physical, social, mental well-being, inspiration, }}{\text { cognitive development, spiritual development, }^{(1)}} \\
\text { nature awareness }\end{array}$ \\
\hline & & \multirow{4}{*}{$\begin{array}{l}\text { Intellectual and } \\
\text { representative } \\
\text { interactions with } \\
\text { natural environment }\end{array}$} & $\begin{array}{l}\text { Characteristics of living systems that } \\
\text { enable scientific investigation or the } \\
\text { creation of traditional ecological } \\
\text { knowledge }\end{array}$ & 3.1.2.1 & $\begin{array}{l}\text { Forested areas are an object of research (e.g., sample } \\
\text { areas, areas where natural developments will not be } \\
\text { altered, } \ldots \text { ) }\end{array}$ & $\begin{array}{l}\text { Knowledge generation about nature and } \\
\text { environmental processes; Derivation of knowledge for } \\
\text { practical applications (Forest management, species } \\
\text { protection, ...) }\end{array}$ \\
\hline & & & $\begin{array}{l}\text { Characteristics of living systems that } \\
\text { enable education and training }\end{array}$ & 3.1.2.2 & $\begin{array}{l}\text { Educational improvement; Transfer, conservation, } \\
\text { development of knowledge }\end{array}$ & $\begin{array}{l}\text { Forested areas where nature-/forest-related topics can } \\
\text { be covered for teaching or training purposes } \\
\text { (e.g., experimental areas, historical practices of } \\
\text { silviculture, ...) }\end{array}$ \\
\hline & & & $\begin{array}{l}\text { Characteristics of living systems that } \\
\text { are resonant in terms of culture or } \\
\text { heritage }\end{array}$ & 3.1.2.3 & $\begin{array}{l}\text { Forested areas where evidence, relicts or traces of } \\
\text { human culture or fossils can be found }\end{array}$ & $\begin{array}{l}\text { Conservation of evidence of human history, geological } \\
\text { development; Improved human awareness about } \\
\text { historical developments of nature, mankind }\end{array}$ \\
\hline & & & $\begin{array}{l}\text { Characteristics of living systems that } \\
\text { enable aesthetic experiences }\end{array}$ & 3.1.2.4 & $\begin{array}{l}\text { Forested areas which are aesthetically attractive or } \\
\text { which have a particularly positive impact on aesthetic } \\
\text { effects of landscape }\end{array}$ & $\begin{array}{l}\text { Improved physical, social, mental well-being; } \\
\text { Improved mental or physical health } \\
{ }^{(1)}\end{array}$ \\
\hline & \multirow{3}{*}{$\begin{array}{l}\text { Indirect, remote, often } \\
\text { indoor interactions } \\
\text { with living systems } \\
\text { that do not require } \\
\text { presence in the } \\
\text { environmental setting }\end{array}$} & $\begin{array}{l}\text { Spiritual, symbolic } \\
\text { and other interactions } \\
\text { with natural } \\
\text { environment } \\
\end{array}$ & $\begin{array}{l}\text { Elements of living systems that have } \\
\text { symbolic meaning }\end{array}$ & 3.2.1.1 & $\begin{array}{l}\text { Forested areas which are representative for specified } \\
\text { types of landscape, cultural artefacts, ecosystems, } \ldots\end{array}$ & Improved sense of place, identity ${ }^{(1)}$, society \\
\hline & & \multirow{2}{*}{$\begin{array}{l}\text { Other biotic } \\
\text { characteristics that } \\
\text { have a non-use value }\end{array}$} & $\begin{array}{l}\text { Characteristics or features of living } \\
\text { systems that have an existence value }\end{array}$ & 3.2.2.1 & $\begin{array}{l}\text { Forested areas with species worthy of protection } \\
\text { (e.g., endangered species, designated protected areas, } \\
\ldots \text {,..) }\end{array}$ & $\begin{array}{l}\text { The right to exist beyond any benefits to human } \\
\text { beings is assumed to be inherent to all living nature (2) }\end{array}$ \\
\hline & & & $\begin{array}{l}\text { Characteristics or features of living } \\
\text { systems that have an option or } \\
\text { bequest value }\end{array}$ & 3.2.2.2 & $\begin{array}{l}\text { Forested areas with species to be conserved for future } \\
\text { generations to enjoy or use }\end{array}$ & $\begin{array}{l}\text { To preserve species and ecosystems for the experience } \\
\text { and use of future generations(e.g., nature forests) }\end{array}$ \\
\hline
\end{tabular}




\subsection{Regulation and Maintenance Services}

Table 4 contains seven CICES Groups, namely Mediation of wastes or toxic substances of anthropogenic origin by living processes, Mediation of nuisances of anthropogenic origin, Regulation of baseline flows and extreme events, Lifecycle maintenance, habitat and gene pool protection, Regulation of soil quality, Water conditions and Atmospheric composition and conditions. Grey-shaded cells at the Class level contain a synthesis between CICES and German FFM guidelines-due to a higher detail of the latter or additional FFM content-not covered in CICES. Relevant Code numbers are extended by letters $(\mathrm{a}-\mathrm{c})$.

In the CICES Division Transformation of biochemical of physical inputs to ecosystems, the CICES Group Mediation of wastes or toxic substances of anthropogenic origin by living processes, is sub-divided into two Classes. Here, the first addition in the CICES Class level took place. Filtration/sequestration/storage/accumulation by micro-organisms, algae, plants, and animals now distinguishes between the local and regional level. The decision to refine this CICES Class is based on the fact, that the federal FFM guideline clearly distinguish between a known emitter (local level; Code 2.1.1.1-a) and an unknown emitter (regional level; Code 2.1.1.1-b) [24]. The CICES Group Mediation of nuisances of anthropogenic origin remains unaltered and contains the CICES Classes Noise attenuation and Visual screening.

Further FFM extensions to CICES can be found in the CICES Division Regulation of physical, chemical, biological conditions. The CICES Group Regulation of baseline flows and extreme events with its original single Class of Control of erosion rates is divided into water- and wind-induced erosion due to the more detailed nature of the FFM guidelines. The Class Control of water induced erosion rates covers the ability of vegetation to anchor the soil and prevent or reduce a leaching of sediments into surface waters (e.g., waterfront protection forests) as well as reducing the water run-off caused by precipitation. Control of wind induced erosion rates includes the ability of forests to reduce wind speed and therefore to reduce the blow-off of soil and humus. The CICES Class Buffering and attenuation of mass movement covers all solid mass movements, mentioned in the FFM guidelines, such as rock slipping, landslides or avalanches. Hydrological cycle and water flow regulation (Including flood control, and coastal protection) describes the ability of forests to regulate the water balance or water retention in order to protect humans, facilities or nature in general against damages, caused by floods. Wind protection describes for instance the actual protection of settlements or storm threatened forest stands against wind or storm as a force of nature and additionally the ability of forests to prevent a blow-in of matter (e.g., snow, fog) into certain areas such as streets. Fire protection describes the ability of special forest areas (e.g., forest fire protection stripes) to protect humans, facilities or nature against fire damages due to a flame-retardant species composition or special dry tree management.

The CICES Group Lifecycle maintenance, habitat and gene pool protection contains the Class Maintaining nursery populations and habitats (Including gene pool protection) and includes the provision of habitats for (endangered) species or improved resistance of species against diseases due to an increased diversity in forest structure.

The CICES Group Regulation of soil quality contains the CICES Class Decomposition and fixing processes and their effect on soil quality and describes humification processes and nutrient inputs into soils by forests to maintain soil characteristics necessary for a human use. Within the CICES Group Water conditions the original CICES Class Regulation of the chemical condition of freshwater by living processes is sub-divided into surface and groundwater, according to the content analysis of the FFM guidelines. The first of these two categories also includes maintaining the water quality of mineral springs. In the last CICES Group Atmospheric composition and conditions, the Class Regulation of chemical composition of atmosphere and oceans covers forests' ability of global climate regulation by sequestering and storing carbon at high performance stands. The CICES Class Regulation of temperature and humidity, including ventilation and transpiration is divided into three spatial scales, due to specific categories in the FFM-guidelines. The micro-climate level describes the impact of forests on small, nearby areas, such as temperature and sunlight regulation on parts of surface waters or single buildings. Regulation of local climate refers to forests, which are protecting nearby, larger objects such as (parts of) agricultural fields 
and forest rejuvenation areas or clusters of several buildings against climate effects such as cold air damages. Regional-level climate regulation covers impacts on wider areas such as climate regulation in densely populated areas or urban agglomerations through an exchange of air masses.

\subsection{Cultural Services}

Table 5 shows the customised CICES Framework for biotic cultural services, identified in the FFM guidelines. The CICES Division Direct, in-situ and outdoor interactions with living systems that depend on presence in the environmental setting contains the CICES Groups Physical and experiential interactions with natural environment and Intellectual and representative interactions with natural environment.

The first CICES Group contains two CICES Classes regarding Characteristics of living systems that enable activities promoting health, recuperation or enjoyment. The difference consists in active or immersive interactions versus passive or observational interactions. The first option describes a recreation service that takes place in forests, but only with a secondary focus on nature, the activity itself serves as the main purpose such as walking, cycling or horse riding. In contrast, the second option is primarily connected to a conscious perception or observation of nature as the main motive, such as forest characteristics, species, smells and sounds. While some of the benefits of these interactions are overlapping, such as an improved physical, social or mental well-being, nature awareness is more pronounced in relation to passive and observational interactions.

The CICES Group Intellectual and representative interactions with natural environment contains four Classes regarding Characteristics of living systems, each with a specific purpose. First, forests provide cultural services for a scientific purpose, generating knowledge about environmental processes or for the creation of traditional ecological knowledge. Second, forests provide cultural services for education and training. Third, they provide ESS in terms of cultural heritage, characteristic for forest areas, which contain evidence, relicts or traces of human culture. Fourth, forests enable aesthetic experiences, which improve the physical, social or mental well-being of humans or their mental health. The CICES Group Spiritual, symbolic and other interactions with natural environment contains the Class Elements of living systems that have symbolic meaning and provides benefits such as an improved sense of place, sense of identity or sense of society. Forest areas providing such services may be representative of specified types of landscape, cultural artefacts or ecosystems. CICES Group Other biotic characteristics that have a non-use value is separated into the two CICES Classes Characteristics or features of living systems that have (1) an existence value and (2) an option or bequest value. The main difference is the temporal perspective. While existence values mainly relate to the present generation, option or bequest values relate to values for future generations. Existence values assume that the right to exist is inherent to all living nature, beyond any benefits to human beings [43]. Option values refer to a potential use of ESS in the future, whereas bequest values relate to preserving species or ecosystems for future generations [44]. Regarding the customised CICES Framework, existence values are inherent in forest areas protected by German Nature Conservation Act, as Article 1 prescribes that nature and landscape are also to be protected based on their intrinsic value [45].

\section{Discussion}

Regarding the methodology applied, the cross-tabulation of FFM categories and the terms used to define and describe forest-related functional aspects in the FFM guidelines (Table 1) has proved crucial in terms of streamlining the content of multiple data sources at state and federal level in Germany. This methodology guaranteed similarities to be identified within the various FFM guidelines and differences in terminology used to be harmonised.

\subsection{Challenges and Opportunities of Aligning FFM and the ESS Concept}

A wide range of forest functions as applied in German FFM could be unambiguously translated into ESS terminology, especially in case of provisioning services and, considering minor adjustments, also in case of regulation and maintenance services. In some cases, challenges emerged in deciding 
which detail of information from FFM or CICES should be considered in the FFM-CICES Synthesis and transferred into the customised CICES Framework to avoid double counting in future accounting studies. For example, due to more detail in FFM guidelines, the original CICES Class Control of erosion rates is now sub-divided into water- or wind-induced erosion (see Section 2). However, a soil protection forest-for example — can provide both services at the same time and same spatial level without being designated for one of these purposes. In order to avoid double counting in such cases, decision makers have to identify and define the prevalent ESS according to the selected spatial and/or temporal scale [46]. Nevertheless, the reviewed FFM guidelines already provide comprehensive, clearly defined criteria for differentiating between relevant FFM categories, sub-categories and related functional aspects of forests, which also supports the identification of primary ESS to be considered.

Since version five of CICES has been released, the framework has been separated into biotic and abiotic ESS to enable a distinction between ESS depending on living systems and those depending on non-living systems [2]. Due to the importance of forests for fresh water provision, which is part of all FFM guidelines, our analysis considered water as the only abiotic ESS for the CICES Section of provisioning services. Other forest-related functional aspects potentially influenced by abiotic factors are much less prominently described in the FFM guidelines and therefore not yet considered in our customised CICES Framework. Nonetheless, they may well be included in a more extended version of a customised CICES Framework for the forest sector. Although relevant information is provided by other expert authorities, rock structures-for example-are mentioned in the federal FFM guideline as geotopes potentially worthy of protection [24]. It is also conceivable that forests for recreational purposes benefit from the presence of caves or rocks, providing abiotic cultural services for cave exploration or rock climbing. Other examples of abiotic ESS can be the generation of energy by wind turbines on forest areas or natural monuments in the form of rock formations. However, before further including abiotic factors into a customised CICES Framework for application in forest agencies or enterprises, it is to be clarified whether these elements should be recognised as a component of forest ecosystems or demarcated as distinct areas.

Regarding our results achieved, we can confirm previous findings highlighting strong similarities between the ESS concept and the FFM approach that have also been put forward by Kindler (2016) [14], Meyer and Schulz (2017) [22] and Bürger-Arndt (2012) [23]. However, building on the harmonised CICES Framework presented in this paper, there are further opportunities in aligning the ESS concept and the FFM approach.

According to Köppel et al. (2016) [12], the ESS concept enables a quantitative perspective. This allows the definition of benchmarks for assessing the state of forest ecosystems. For example, Seif 2017 [47] has developed target condition indicators (Zielzustandsindikatoren) for forest ESS supply, to derive measures towards maintaining or optimising certain ESS. Furthermore, the supply side-orientated FFM approach can be extended by a demand side perspective, considering ESS in decision-making processes, an improved collaboration of different stakeholders or by valuing forest ESS in view of social, cultural or economic perspectives.

However, there are also challenges. It should be kept in mind that FFM has been developed to identify and map forest functions in addition to timber provision, given that timber provision has always been accounted for in forest enterprises [11]. Therefore, the customised CICES Framework presented in this paper falls short of a number of provisioning services related to timber or other forest products that have always been part of the forest agencies' or enterprises' traditional cost- and performance accounting procedures. This also holds for further provisioning services such as game, fish or Christmas trees.

Further forest-related provisioning services mentioned in the international literature are not taken into account by the FFM guidelines due to the German legal and institutional framework. For example, Saastamoinen et al. (2014) [30] or Hansen and Malmaeus (2016) [31] also take into account livestock farming and collecting plants or mushrooms. In Germany, the consideration of livestock farming in forests proves difficult due to federal acts. Livestock farming is in most cases considered as a conversion 
of forest into other land-use types and therefore generally prohibited by law [48]. In contrast, the provision of venison causes less problems in Germany, and data are more easily available. For example, in their annual reports, the state forest agencies of Saxony [49] and Bavaria [50] provide detailed information about the amount and revenues of killed game. To sum up, if forest ESS are to be assessed holistically, a careful discussion of which ESS to be included or not is necessary, yet, legal regulations of relevant countries are to be respected.

\subsection{The Way Forward}

Although the research results presented here are clearly based on German framework conditions including characteristics at German state and federal levels, the principle of FFM is also used in other Central European countries [16]. Therefore, the customised CICES Framework should be transferable to other countries using FFM, but even beyond, due to the wide applicability of the differentiated approach of FFM in Germany. However, this needs to be adapted to context, as the criteria for determining most important ESS may need to be applied to other governmental and forestry structures.

Due to CICES' ability to link data on ecosystem structures, dynamics of ecosystems and information on economic performance [29], the customised CICES Framework bears the opportunity to serve as an accounting framework in terms of SEEA Experimental Ecosystem Accounting [28]. The customised CICES Framework developed here is but a first step to identify and assess forest ESS at a biophysical level. For ecosystem accounting to move further, economic values of forest ESS are needed.

Next to market valuation methods, revealed and stated preference methods are applied to assess the economic value of ecosystem services [51-53]. Elsasser et al. [20] already provide a bibliography and database on forest ecosystem service valuation studies in Austria, Germany and Switzerland. As primary valuation studies may be time-consuming and expensive, benefit transfer methods use existing valuation studies to transfer values from the case study site to the policy site of interest [54].

Yet, challenges remain. For example, not all available methods are undisputed. For non-use values, such as existence or bequest values, monetary values can only be estimated using stated preference methods [52]. Schweppe-Kraft and Grunewald (2015) [53] raise concerns whether the respondents' statements about their willingness-to-pay actually reflect their real preferences. They also attach great importance to the formulation of questions asked in such studies and the selection of goods examined in order to make the results robust for decision-making. According to Sukhdev et al. (2014) [55] it is also essential to carefully communicate the purpose of economic valuation studies, which dimensions have been taken into account and how the results are to be interpreted. Ring et al. (2010) [56] point to ecological, economic and political challenges related to the economics of ecosystems and biodiversity; among them our ignorance about ecosystem thresholds and uncertainties associated with the relationship between biodiversity and ecosystem services or socio-cultural considerations that may limit the range of valid cases for marginal valuation [57].

Although there is an increasing number of studies, e.g., by Waldgenossenschaft Remscheid [58] or Hansen and Malmaeus (2016) [31], there remains much to be done in this direction. Siebert (2014) [58] calculated that the proceeds from timber sales in the city forest of Remscheid, Germany only account for $2.6 \%$ of the total value of all ESS accounted for. Therefore, a future challenge consists in assessing the economic value especially of regulating and maintenance services as well as cultural services that have thus far not been accounted for in forest business accounting procedures. Another related problem for ecosystem accounting lies in the partial incompatibility of environmental-economic accounting in the framework of national accounting with non-market valuation methods used for environmental valuation. SEEA Experimental Ecosystem Accounting prefers market prices and cost-based approaches—-thus values not including the consumer surplus [59] — while many non-market valuation methods such as contingent valuation or choice modelling include the consumer surplus in the economic values derived. 
Balancing different needs and demands of forests could be another future challenge. Anderson et al. (2000) [60] emphasise the importance of considering various interests in forest planning, such as water quality, social values or biomass production. Therefore, the classical forest stand perspective should be extended by a landscape level approach [60]. Although the customised CICES Framework could be used in monitoring and information systems towards a landscape-based forestry planning, its suitability remains to be tested.

\section{Conclusions}

In the context of considering natural capital in decision making, the ESS concept is steadily increasing in importance. This also holds for the forest sector in Germany. In search for a harmonised set of terminology compatible with ESS classifications, the FFM method that is applied in Germany and a number of Central European countries as a common way to assess the multifunctional benefits of forests is used as a starting point [16].

Due to the federal multi-level governance system in Germany, the various forest function categories across German states were harmonised as a basis to relate them to the ESS concept. This bottom-up approach has been combined with a top-down approach, building on CICES with the aim of developing a harmonised, methodological framework, suitable for accounting forest-related ESS, as a step towards future ESS monitoring and reporting commitments in the forest sector.

As a main result, the customised CICES Framework provides a synthesis between German FFM and CICES at CICES Class level. Furthermore, by way of providing forest-related examples and descriptions of the forest-relevant CICES Classes, decision makers and various stakeholders in the forest sector are supported in further developing their existing data bases of FFM towards a revised data base of ESS. Due to the bottom-up approach starting at state level, regional particularities are taken into account to ensure an application on forests across the entirety of Germany.

Due to the ability of the CICES Framework to link data on ecosystem structures, dynamics of ecosystems and information on economic performance [29], the customised CICES Framework bears the opportunity to serve as an accounting framework for SEEA Experimental Ecosystem Accounting [28] in the future to enable a biophysical evaluation and accounting for the economic value of forest ESS. Accordingly, an important step towards realising national, European and international biodiversity and forestry strategies is made.

Author Contributions: A.T. conceptualised the study and the methodology, conducted the formal data analysis, data investigation and visualised the data. A.T. also wrote the original draft. I.R. supervised the research, reviewed and edited the article. A.T. and I.R. contributed to discuss and evaluate the main contents and approved the final manuscript.

Funding: This research received no external funding.

Acknowledgments: The authors would like to thank Peter Deegen for constructive discussions and very helpful comments on an earlier version of this manuscript. We would also like to thank Renate Bürger-Arndt for providing insights into her own research on the topic, and sharing her knowledge on the state-of-the-art of considering the ESS concept in forest planning practice. Finally, we are grateful to the state forest agencies of Baden-Württemberg, Bavaria, Brandenburg, Bremen, Hamburg, Hesse, North Rhine-Westphalia, Rhineland-Palatinate, Saarland, Saxony, Schleswig-Holstein, and Thuringia for providing valuable information on the state's forest function mapping approach. While retaining responsibility for any remaining errors, we would like to thank three anonymous reviewers for constructive and very helpful feedback.

Conflicts of Interest: The authors declare no conflict of interest.

\section{References}

1. FAO. Global Forest Resources Assessment 2015; Food and Agriculture Organization of the United Nations: Rome, Italy, 2015.

2. Haines-Young, R.; Potschin, M. Common International Classification of Ecosystem Services (CICES) V5.1: Guidance on the Application of the Revised Structure. Available online: www.cices.eu (accessed on 5 November 2018). 
3. Meyers, N. The World's Forests and Their Ecosystem Services. In Nature's Services: Societal Dependence on Natural Ecosystems; Daily, G., Ed.; Island Press: Washington, DC, USA, 1997; pp. 215-237, ISBN 1-55963-475-8.

4. Daniel, T.C.; Muhar, A.; Arnberger, A.; Aznar, O.; Boyd, J.W.; Chan, K.M.A.; Costanza, R.; Elmqvist, T.; Flint, C.G.; Gobster, P.H.; et al. Contributions of cultural services to the ecosystem services agenda. Proc. Natl. Acad. Sci. USA 2012, 109, 8812-8819. [CrossRef] [PubMed]

5. European Commission. A New EU Forest Strategy: For Forests and the Forest-Based Sector; European Commission: Brussels, Belgium, 2013.

6. European Commission. Our Life Insurance, Our Natural Capital: An EU Biodiversity Strategy to 2020; European Commission: Brussels, Belgium, 2011.

7. Bundesministerium für Umwelt, Naturschutz, Bau und Reaktorsicherheit (BMUB). Nationale Strategie zur Biologischen Vielfalt; BMUB: Berlin, Germany, 2007.

8. Riegert, C.; Bader, A. German Cultural History of Forestry and Forest Functions since the Early 19th Century. Available online: https:/ / editors.eol.org/ eoearth/index.php?title=German_cultural_history_of_forestry_ and_forest_functions_since_the_early_19th_century\&oldid=129409 (accessed on 5 November 2018).

9. Zwierlein, K.A. Vom großen Einfluss der Waldungen auf Kultur und Beglückung der Staaten mit Besonderer Hinsicht auf Polizei; Stahel: Würzburg, Germany, 1806.

10. De Jonnès, M. Première Mémoire sur le Déboisement des Forêts; P.J. de Mat: Brussels, Belgium, 1825.

11. Dieterich, V. Forstwirtschaftspolitik—Eine Einführung; Parey: Hamburg, Germany, 1953.

12. Köppel, J.; Siegmund-Schultze, M.; Albert, C.; Bürger-Arndt, R.; Evers, M.; Fischer, C.; Freese, J.; Galler, C.; von Haaren, C.; Jedicke, E.; et al. Stand und Potenziale der Integration des Ökosystemleistungskonzeptes in bestehende Planungs-, Regelungs- und Anreizmechanismen. In Ökosystemleistungen in ländlichen Räumen-Grundlage für Menschliches Wohlergehen und nachhaltige wirtschaftliche Entwicklung; von Haaren, C., Albert, C., Eds.; Leibniz Universität Hannover, Helmholtz-Zentrum für Umweltforschung-UFZ: Hannover, Leipzig, Germany, 2016; pp. 246-307.

13. Paletto, A.; Ferretti, F.; Cantiani, P.; De Meo, I. Multi-functional approach in forest landscape management planning: An application in Southern Italy. For. Syst. 2012, 21, 68-80. [CrossRef]

14. Kindler, E. A comparison of the concepts: Ecosystem services and forest functions to improve interdisciplinary exchange. For. Policy Econ. 2016, 67, 52-59. [CrossRef]

15. Millennium Ecosystem Assessment. Ecosystems and Human Well-Being: Synthesis; Island Press: Washington, DC, USA, 2005; ISBN 1597260401.

16. Simoncic, T.; Boncina, A.; Rosset, C.; Binder, F.; De Meo, I.; Cavlovic, J.; Gal, J.; Matijasic, D.; Schneider, J.; Singer, F.; et al. Importance of priority areas for multi-objective forest planning: A Central European perspective. Int. For. Rev. 2013, 15, 509-523. [CrossRef]

17. Bundeswaldgesetz. Gesetz zur Erhaltung des Waldes und zur Förderung der Forstwirtschaft (Bundeswaldgesetz-BWaldG); Bundesgesetzblatt: Bonn, Germany, 2017.

18. Matero, J.; Saastamoinen, O. In search of marginal environmental valuations-ecosystem services in Finnish forest accounting. Ecol. Econ. 2007, 61, 101-114. [CrossRef]

19. Bürger-Arndt, R. Waldfunktionen und Ökosystemleistungen im wissenschaftlichen Diskurs. In BfN-Skripten 334: Der Nutzen von Ökonomie und Ökosystemleistungen für die Naturschutzpraxis—Workshop III: Wälder; Ring, I., Ed.; Bundesamt für Naturschutz (BfN): Bonn-Bad Godesberg, Germany, 2013; pp. 24-30.

20. Elsasser, P.; Meyerhoff, J.; Weller, P. An Updated Bibliography and Database on Forest Ecosystem Service Valuation Studies in Austria, Germany and Switzerland; Thünen Working Paper 65; Johann Heinrich von Thünen-Institut: Hamburg, Germany, 2016.

21. Hanewinkel, M. Multifunktionalität des Waldes. In Der Multifunktionale Wald—Konflikte und Lösungen; Forum für Wossen 2011; Eidgenössische Forschungsanstalt für Wald, Schnee und Landschaft: Birmensdorf, Switzerland, 2011; pp. 7-14.

22. Meyer, M.A.; Schulz, C. Do ecosystem services provide an added value compared to existing forest planning approaches in Central Europe? Ecol. Soc. 2017, 22, 1-6. [CrossRef]

23. Bürger-Arndt, R.; Ohse, B.; Meyer, K. Fazit und Empfehlungen zur Weiterentwicklung des Ökosystemdienstleistungsansatzes für Wälder. In Ökosystemdienstleistungen von Wäldern-Workshopbericht; Bürger-Arndt, R., Ohse, B., Meyer, K., Höltermann, A., Eds.; Bundesamt für Naturschutz (BfN): Bonn-Bad Godesberg, Germany, 2012; pp. 126-138. 
24. Abiy, M.; Baum, C.; Bergen, P.; Blum, M.; Chmara, M.; Ensinger, K.; Franz, S.; Kilian, K.; Kranz, K.; Kreten, R.-M.; et al. Leitfaden zu Kartierung der Schutz und Erholungsfunktionen des Waldes-Waldfunktionenkartierung (WFK); Projektgruppe Waldfunktionenkartierung der AG Forsteinrichtung c/o Forstliche Versuchs- und Forschungsanstalt Baden-Württemberg: Freiburg, Germany, 2015; ISBN 9783000518997.

25. Bürger-Arndt, R. Kategorien, Indikatoren und Datenlage der Waldfunktionenkartierung. In Ökosystemdienstleistungen von Wäldern-Workshopbericht; Bürger-Arndt, R., Ohse, B., Meyer, K., Höltermann, A., Eds.; Bundesamt für Naturschutz (BfN): Bonn-Bad Godesberg, Germany, 2012; pp. 51-54.

26. Pistorius, T.; Schaich, H.; Winkel, G.; Plieninger, T.; Bieling, C.; Konold, W.; Volz, K.R. Lessons for REDDplus: A comparative analysis of the German discourse on forest functions and the global ecosystem services debate. For. Policy Econ. 2012, 18, 4-12. [CrossRef]

27. De Groot, R.; Fisher, B.; Christie, M.; Aronson, J.; Braat, L.; Gowdy, J.; Haines-Young, R.; Maltby, E.; Neuville, A.; Polasky, S.; et al. Integrating the Ecological and Economic Dimensions in Biodiversity and Ecosystem Service Valuation. In The Economics of Ecosystems and Biodiversity (TEEB): Ecological and Economic Foundations; Kumar, P., Ed.; Earthscan: London, UK, 2010; pp. 9-40, ISBN 9781849712125.

28. United Nations; European Union; Food and Agriculture Organization of the United Nations; Organisation for Economic Co-operation and Development; World Bank. System of Environmental-Economic Accounting 2012: Experimental Ecosystem Accounting; United Nations: New York, NY, USA, 2014; ISBN 978-92-1-161575-3.

29. Haines-Young, R.; Potschin, M. Proposal for a Common International Classification of Ecosystem Goods and Services (CICES) for Integrated Environmental and Economic Accounting; European Environment Agency: Copenhagen, Denmark, 2010.

30. Saastamoinen, O.; Matero, J.; Horne, P.; Kniivilä, M.; Haltia, E.; Vaara, M.; Mannerkoski, H. Classification of Boreal Forest Ecosystem Goods and Services in Finland; Reports and Studies in Forestry and Natural Sciences, No. 11; University of Eastern Finland: Joensuu, Finland, 2014.

31. Hansen, K.; Malmaeus, M. Ecosystem services in Swedish forests. Scand. J. For. Res. 2016, 31, 626-640. [CrossRef]

32. EUSTAFOR; Patterson, T. Ecosystem Services in European State Forests; European State Forest Association: Brussels, Belgium, 2011.

33. Simončič, T.; Spies, T.A.; Deal, R.L.; Bončina, A. A Conceptual Framework for Characterizing Forest Areas with High Societal Values: Experiences from the Pacific Northwest of USA and Central Europe. Environ. Manag. 2015, 56, 127-143. [CrossRef] [PubMed]

34. Haines-Young, R.; Potschin, M. CICES V5.1_Mar2018. Available online: https://cices.eu/resources (accessed on 3 July 2018).

35. Polley, H.; Hennig, P. Waldeigentum im Spiegel der Bundeswaldinventur. AFZ-DerWald 2015, 6, 34-36.

36. Landesforstanstalt Mecklenburg-Vorpommern. Waldfunktionenkartierung Mecklenburg-Vorpommern 2006; Landesforstanstalt Mecklenburg-Vorpommern: Malchin, Germany, 2006.

37. Niedersächsische Landesforsten. Waldfunktionenkarte Niedersachsen-Allgemeine Erläuterungen; Niedersächsische Landesforsten: Hannover, Germany, 2003.

38. Groß, J.; Müller, K. Waldfunktionen im Land Brandenburg; Eberswalder Forstliche Schriftenreihe Band XXXIV; Ministerium für Ländliche Entwicklung Umwelt und Verbraucherschutz; Landesforstanstalt Eberswalde: Potsdam und Eberswalde, Germany, 2007.

39. Staatsbetrieb Sachsenforst. Waldfunktionenkartierung-Grundsätze und Verfahren zur Erfassung der besonderen Schutz-und Erholungsfunktionen des Waldes im Freistaat Sachsen; Staatsbetrieb Sachsenforst: Pirna, OT Graupa, Germany, 2010.

40. Thüringer Landesanstalt für Wald, Jagd und Fischerei. Waldfunktionenkartierung im Freistaat Thüringen; Thüringer Landesanstalt für Wald, Jagd und Fischerei: Gotha, Germany, 2006.

41. Landesforsten Rheinland-Pfalz. Erläuterungen zur digitalen Waldfunktionenkarte Rheinland-Pfalz; Landesforsten Rheinland-Pfalz: Koblenz, Germany, 2009.

42. Mayring, P.; Fenzi, T. Qualitative Inhaltsanalyse. In Handbuch Methoden der empirischen Sozialforschung; Baur, N., Blasius, J., Eds.; Springer VS: Wiesbaden, Germany, 2014; pp. 543-556, ISBN 978-3-531-18939-0. 
43. Turkelboom, F.; Raquez, P.; Dufrêne, M.; Raes, L.; Simoens, I.; Jacobs, S.; Stevens, M.; De Vreese, R.; Panis, J.A.E.; Hermy, M.; et al. CICES Going Local: Ecosystem Services Classification Adapted for a Highly Populated Country. In Ecosystem Services: Global Issues, Local Practices; Jacobs, S., Dendoncker, N., Keune, H., Eds.; Elsevier: Amsterdam, The Netherlands, 2013; pp. 223-247, ISBN 9780124199644.

44. De Groot, R.S.; Alkemade, R.; Braat, L.; Hein, L.; Willemen, L. Challenges in integrating the concept of ecosystem services and values in landscape planning, management and decision making. Ecol. Complex. 2010, 7, 260-272. [CrossRef]

45. Bundesnaturschutzgesetz. Gesetz über Naturschutz und Landschaftspflege (Bundesnaturschutzgesetz-BNatSchG); Bundesgesetzblatt: Bonn, Germany, 2017.

46. Fu, B.-J.; Su, C.-H.; Wei, Y.-P.; Willett, I.R.; Lü, Y.-H.; Liu, G.-H. Double counting in ecosystem services valuation: Causes and countermeasures. Ecol. Res. 2011, 26, 1-14. [CrossRef]

47. Seif, C.I. On the Contribution of German-Speaking Literature Concerning the Assessment of Forest Effects as a Basis to Provide Ecosystem Services of Managed Forests. Master's Thesis, Georg-August-Universität Göttingen, Göttingen, Germany, 23 January 2017.

48. Luick, R.; Schuler, H.-K. Waldweide und forstrechtliche Aspekte. In Berichte des Instituts für Landschaftsund Pflanzenökologie der Universität Hohenheim-Heft 17; Fangmeier, A., Böcker, R., Eds.; Universität Hohenheim, Institut für Landschafts- und Pflanzenökologie: Stuttgart, Germany, 2008; pp. 149-164, ISBN 978-3-9811595-2-3.

49. Staatsbetrieb Sachsenforst. Sachsenforst 2016-Geschäftsbericht; Staatsbetrieb Sachsenforst: Pirna, OT Graupa, Germany, 2017.

50. Bayerische Staatsforsten Anstalt des öffentlichen Rechts. Jahresabschluss 2017; Bayerische Staatsforsten: Regensburg, Germany, 2017.

51. Bateman, I.; Mace, G.; Fezzi, C.; Atkinson, G.; Turner, K. Economic Analysis for Ecosystem Service Assessments. Environ. Resour. Econ. 2011, 48, 177-218. [CrossRef]

52. Pascual, U.; Muradian, R.; Brander, L.; Gómez-Baggethun, E.; Martín-López, M.; Verma, M.; Armsworth, P.; Christie, M.; Cornelissen, H.; Eppink, F.; et al. The economics of valuing ecosystem services and biodiversity. In The Economics of Ecosystems and Biodiversity: Ecological and Economic Foundations; Chapter, 5, Kumar, P., Eds.; Earthscan: London, UK; Washington, DC, USA, 2010; pp. 183-256.

53. Schweppe-Kraft, B.; Grunewald, K. Approaches to the Economic Valuation of Natural Assets. In Ecosystem Services-Concept, Methods and Case Studies; Grunewald, K., Bastian, O., Eds.; Springer: Heidelberg, Germany, 2015; pp. 85-104.

54. Johnston, R.J.; Rolfe, J.; Rosenberger, R.S.; Brouwer, R. Benefit Transfer of Environmental and Resource Values: A Guide for Researchers and Practitioners; Springer: Dordrecht, The Netherlands, 2015.

55. Sukhdev, P.; Wittmer, H.; Miller, D. The Economics of Ecosystems and Biodiversity (TEEB): Challenges and Responses. In Nature in the Balance: The Economics of Biodiversity; Helm, D., Hepburn, C., Eds.; Oxford University: Oxford, UK, 2014; pp. 1-14.

56. Ring, I.; Hansjürgens, B.; Elmqvist, T.; Wittmer, H.; Sukhdev, P. Challenges in framing the economics of ecosystems and biodiversity: The TEEB initiative. Curr. Opin. Environ. Sustain. 2010, 2, 15-26. [CrossRef]

57. Turner, R.K.; Paavola, J.; Cooper, P.; Farber, S.; Jessamy, V.; Georgiou, S. Valuing nature: Lessons learned and future research directions. Ecol. Econ. 2003, 46, 493-510. [CrossRef]

58. Siebert, L. Inwertsetzung von Ökosystemdienstleistungen: Eine objektive Bewertung auf lokaler Ebene-Eine Studie im Auftrag der Waldgenossenschaft Remscheid eG; Waldgenossenschaft Remscheid eG: Remscheid, Germany, 2014.

59. Obst, C.; The Valuation of Ecosystem Services and Assets for SEEA Ecosystem Accounting. Background paper on SEEA EEA Approach to Valuation Prepared for the BfN/UNSD Workshop on Ecosystem Valuation. Available online: https:/ / www.fresh-thoughts.eu/userfiles / file/Ecosystemaccountingvaluationprinciples_ Bonnworkshop.pdf (accessed on 5 November 2018).

60. Andersson, F.O.; Feger, K.H.; Hüttl, R.F.; Kräuchi, N.; Mattsson, L.; Sallnäs, O.; Sjöberg, K. Forest ecosystem research-Priorities for Europe. For. Ecol. Manag. 2000, 132, 111-119. [CrossRef]

(C) 2018 by the authors. Licensee MDPI, Basel, Switzerland. This article is an open access article distributed under the terms and conditions of the Creative Commons Attribution (CC BY) license (http:/ / creativecommons.org/licenses/by/4.0/). 